OPEN ACCESS

Edited by:

Francesca Fulminante,

Roma Tre University, Italy

Reviewed by:

Oliver Nakoinz,

Christian-Albrechts-Universität zu

Kiel, Germany

Carl Knappett,

University of Toronto, Canada

Alan Wilson,

University College London, UK

${ }^{*}$ Correspondence:

Clara Filet

clara.filet@gmail.com

Specialty section:

This article was submitted

to Digital Archaeology,

a section of the journal

Frontiers in Digital Humanities

Received: 20 September 2016

Accepted: 20 December 2016

Published: 14 February 2017

Citation:

Filet C (2017) An Attempt to Estimate

the Impact of the Spread of

Economic Flows on

Latenian Urbanization.

Front. Digit. Humanit. 3:10.

doi: 10.3389/fdigh.2016.00010

\section{An Attempt to Estimate the Impact of the Spread of Economic Flows on Latenian Urbanization'}

\author{
Clara Filet* \\ UMR 8546 'AOROC, Celtes et Etrusques', UMR 7041 'ArScAn, Archéologies Environnementales', EA 4543 'SAMM', \\ University Paris 1, Paris, France
}

Over a relatively short period between the end of the fourth and the middle of the first century BC, an unprecedented process of urbanization developed in non-Mediterranean Europe. Among all the factors contributing to the rise of the first agglomerations possessing urban characteristics in this area, this article focuses on the role of commercial interactions. The ability of settlements to interact within the trade network is approached by modeling of interactions. The aim is to provide new material to estimate the extent to which this factor could have impacted the known hierarchy of settlements on the one hand, and its role in the development of the Latenian urbanization process on the other hand.

Keywords: spatial interactions, modeling, La Tène, urbanization, trade

\section{INTRODUCTION}

Rediscovered at the end of the nineteenth century, the large agglomerations of Latenian Europe testify that a major urbanization process occurred at the end of the Iron Age. Over the last few decades, modern archeology has succeeded in putting this phenomenon in the context of the large economic and social upheavals of the three last centuries BC. Among the factors that fostered the emergence of the first urban centers in this part of Europe, an increase of artisanal production and the explosion of intersite exchange have long been identified as crucial.

The present study aims to investigate the latter. We try to estimate the extent to which the trade factor is relevant for explaining the development and the prosperity of certain agglomerations. Archeological data are complementarily used in connection with modeling of interactions to perceive how far the ability of settlements to interact inside the trade network had an impact on their known hierarchy. The aim is not to provide statements about individual sites based on their location in the local scale landscape, but a comprehensive overview based on the settlement pattern of agglomerations in Central-Eastern Gaul.

This work is still in progress. For now, we will present the main issues, the methodology and the use of the model, the parameters we take into account, and the expected results.

\footnotetext{
${ }^{1}$ This article is part of a doctoral project in progress at the Panthéon-Sorbonne University (Paris 1), "Dynamiques d'urbanisation et réseaux sociaux dans le monde celtique translapin du IV au I siècle avant J.-C.," directed by Patrice Brun.
} 


\section{CONTEXT: LATENIAN URBANIZATION}

\section{Back to La Tène Times}

The four last centuries $\mathrm{BC}$ appear as a truly pivotal period for non-Mediterranean western and central Europe. From the Atlantic coast line to Romania, archeologists highlight an unprecedented economic boom, greatly increasing both agricultural and artisanal production (Malrain et al., 2002; Marion, 2013). New products (such as iron tools, painted wares, or glass bracelets) were widely spread over hundreds of kilometers (Pierrevelcin, 2010), while trade with the Mediterranean states flooded the market with thousands of amphorae every year (Olmer et al., 2013). This period marked also the introduction of coins in the economy (Gruel, 1989).

Social complexification can be perceived through the increasing hierarchy of settlements and the development of a high concentration of dwellings (Malrain, 2000; Fernández-Götz et al., 2014). Indeed, this context formed the ideal setting for the emergence of the urbanization. Specifically, the third and the second centuries BC saw the appearance of large agglomerations (7-15 ha on average, to much larger-Augstein, 2006). The importance of these agglomerations for their commercial and craft activities has long been noticed (Collis et al., 2000; Fichtl, 2013). From the second half of the second century BC, large sites that could stretch over several hundred hectares are gradually founded. The usual location of sites on hilltops, often surrounded by a rampart, indicates a strong political power. This political power contributes to the progressive diversification in the functions played by grouped habitats, alongside their prominence in terms of economic and religious weight (Fernández-Götz, 2014b; Filet, 2014). The embedding of these large agglomerations in the interaction network, with their strong role in attractiveness and redistribution of people and goods, gives some of them the characteristics of real cities (Collis, 1984; Fichtl, 2005; Filet, 2014; Brun, 2015 ).

The development of these first urban networks north of the Alps works alongside a process of territorial structuring. In the western part of the area, the Gallic Civitates developed as political and territorial entities. They were the first form of archaic states in this area (Fernández-Götz, 2014a). Their organization was preserved long after the Roman conquest, through the Roman Civitates, then the medieval dioceses.

\section{Latenian Urbanization Process: Preliminary Explanations}

The complexification of the settlement pattern and of modality of habitation developed in non-Mediterranean Europe took less than two centuries to move out of a system of small rural settlements, first to large open agglomerations that polarized human and economical flows, then to genuinely urban centers. This unprecedented evolution of the settlement structure and of the social connections that derived from it has been addressed at length by the community of protohistorian archeologists. In the last two decades, different viewpoints have been put forward to explain the emergence of this pre-Roman urbanization.
The probable influence of the migration of Celtic people from northern Italy or the role of the Greek colonies in southern France has long been discussed (Kruta and Goudineau, 1980; Fichtl, 2012). Other explanations, however, have focused on religious factors, leading people to gather around public places and sanctuaries (Metzler, 1995; Fichtl et al., 2000; Fernández-Götz, 2014b), or on economic forces, by emphasizing the role of the earlier open agglomerations and their importance for production and trade (Lallemand, 2008; Salač, 2014). Further, Vaginay (2000) has proposed a reinforcement of the landed elite restoring their control of the economic wealth.

However, many researchers have rejected a monolithic explanation, opposing external influence (proximity to Rome, war, etc.), and internal (complexification by cycles and peaks). Indeed, varied rhythms and phenomena manifested themselves differently from one region to another. From this viewpoint, we are not studying a general dynamic that could be explained by a universal model, but several sociopolitical dynamics acting mostly on local scales (Moore and Ponroy, 2014). However, this statement could result in the inverse problem; that is to say, forgetting the rapidly growing contacts in Latenian Europe and beyond, and the strong economic and cultural connections between those regions. Urbanization appeared in most of Latenian Europe at the end of La Tène period, in a period of great diffusion of products, ideas, and values. Social interactions at large scale and social contacts were completely usual and had a strong effect on the diffusion of urbanization, even if the expression of the processes is slightly different from one region to another due to the local context, reception, and adaptation of various local groups.

Those oppositions between internal vs. external explanations and global vs. local factors are abundant in the literature about urbanization in the La Tène. We cannot forget that this phenomenon is definitely to be considered as "complex" in a strong sense; that is to say, the result of local events and global effects (Bar-Yam, 2003). This kind of system, which is characteristic of most of human societies, is well studied in other disciplines. It holds, as a fundamental principle, that there is neither one explanation nor one scale of explanation for those types of phenomena.

It also means that we have to distinguish between the process itself, its global factors and local expressions, and the individual factors involved in the emergence of one specific agglomeration. For example, if an agglomeration was created at a certain location, because there were mines to exploit, that does not directly imply that mines are a direct factor in the urbanization process. In other words, we should be careful to differentiate between the reasons why at the end of the Iron Age people started to gather and the benefits in gathering, and why they chose to gather in a specific area.

Studying the Latenian urbanization process thus implies having to deal with a range of factors and explanations working at different scales. We will never be able to represent all of them in a single scheme, with their relative importance varying from a region to another. However, we can start to work by highlighting the most important ones and try to measure their impact at these different scales. 
This particular study will focus on only one of the factors: how the connection to the main trade flows came to determine the prosperity of some agglomerations.

\section{ISSUES: TRADE FLOWS, LOCATION OF SITES, AND URBAN PROSPERITY}

In geography, flows are defined as an aggregated measure of movements observed during a long period (Pumain and SaintJulien, 2010). By trade flows, we understand the amount of the movements of goods that aim to be exchanged, sold, or bought.

\section{What Makes Some Agglomerations Attractive for Merchants?}

What drew the merchants to a particular agglomeration? A range of reasons can be assumed. They would have changed from a period to another and from a type of merchant to another.

I. Concentration of population

- Permanent presence: large and constant population that constitutes an important market of potential clients and allows "agglomeration economies";

- Episodic presence: regular concentration of population for cultural ceremonies, assemblies, etc.;

II. Important commercial activities

- Presence of other merchants: optimization between supply and market opportunities. Concentration of trade activities, where a merchant can buy, cooperate, and resell;

III. Important production activities

- Presence of specialized craftsmen producing diversified and desired goods of high quality;

- Proximity with specific resources and highly specialized production (like mines, salt, etc.);

IV. Favorable political authority

- Authority that is a good customer: prestigious goods;

- Authority that facilitates the installation: low taxes;

V. Ease of access

- Accessibility: easy to access from the main circulation axis, cost effective travel;

- Visibility and reputation: place known and valued by merchants;

VI. Tradition

- Habit: ancient market place or trade fair still used by tradition.

Hence, the importance of an agglomeration as a trading center can be mainly due to

(a) its close location to the main circulation and trade axis;

(b) its situation as a redistribution center for settlements of lower importance;

(c) its border location and situation as a mandatory intermediary;

(d) its proximity to raw material sources and concentration of craftsmen;

(e) its high status.
It is the sites' location in relation to the main communication axes that interests us here. We are looking for a way to approach (and of course not resolve) the issue of regions and sites situated well enough (or not) to take advantage of the long-distance diffusion of manufactured products. We do not take into account goods locally produced and used, such as agricultural products.

\section{Problematics}

Many authors have already highlighted how far the number and the extent of interactions (economic, political, demographic streams, and circulation of ideas) may have contributed to the emergence and the prosperity of some towns (Garmy, 2012; Rivers et al., 2013). For the commercial sphere in particular, an advantageous location in relation to main communication roads may have strongly affected the wealth of some agglomerations. This has been discussed for several towns in Latenian Gaul, in particular Roanne (Loire), Varennes-sur-Seine (Yonne), and Varennes-sur-Allier (Allier), which are all situated at a river confluence or a major crossroad (Séguier, 1996; Lallemand, 2008; Barral and Lallemand, 2014). However, if being well-located matters in terms of economic and urban prosperity, a range of other factors may have also played a role. The perfect counter example is Bibracte: the political capital and commercial hub of one of the most powerful Celtic civitates, the Aedui. The city stood in the mountainous region of Morvan (Burgundy), isolated from major waterway routes and crucial terrestrial roads joining the Saône river to the Seine (Kasprzyk and Nouvel, 2010). The location should then have been chosen for other reasons, including previous religious status (Fernández-Götz, 2014b) or metal mines (Cauuet and Tamas, 2008).

Therefore, if we want to go beyond those statements regarding individual cases, the issue needs to be addressed in a more comprehensive way: to what extent an advantageous location inside the exchange networks may have been a factor in the development and the prosperity of certain agglomerations? This question calls for a systemic analysis. We need to consider our set of sites as a group of interacting entities, in which localized phenomena may have had influences on other parts of the system, and thus allows us to work on the spread of flows dynamically. We want to be able to estimate which sites, types of sites, and regions are basically favored by their location in relation to commercial axes and flows. In other words, we try to evaluate the economic attractiveness of agglomerations according to their position in the global network of grouped habitats.

\section{DATA AND PARAMETERS}

\section{Area of Study and Quality of Data}

The studied area consists of a large region of $230,000 \mathrm{~km}^{2}$, which mainly covers the central and eastern Gaul, from central France to Luxembourg and western Germany. This zone is now quite well documented because of a rich activity of rescue archeology and recent regional studies (Feliu, 2008; Lallemand, 2008; Krausz, 2014). During the late La Tène time, it comprised some 20 political entities. From the major Civitates of central Gaul (Aedui or 
Bituriges) to the smallest ones north of the Seine river, a large diversity of economic and political weight can be explored.

The definition of the corpus was kept as broad as possible. It aims to consider every grouped settlement from small hamlets from 1 ha to big cities, combining open and fortified sites, to better perceive the role of each type and size sample in the modeled process. This open definition then allows specific selections when running the model, such as excluding the smallest sites or the open agglomerations. All in all, 325 settlements were indexed, in a range of 1 to more than 200 ha (Figure 1). ${ }^{2}$ Three time slices were delimited on relative dating: LT C2, LT D1, and LT D2, which covers the last two centuries BC. The fourth time slice corresponds to a general state of settlements during La Tène D (150-25 BC).

Even if this inventory offers a quite large overview of the settlement pattern in eastern Gaul, we cannot claim it to be the exact reflection of land occupation at La Tène time. As always in archeology, an inventory reflects a state of the art and is always to be completed in the future. We have to be aware of the limits and the omissions in our data, and how they can affect the results. This primary analysis has been undertaken with the creation of confidence maps to evaluate heterogeneity of data and the weight of poorly investigated regions ${ }^{3}$ (Oštir et al., 2008).

\section{Transport of Goods in Latenian Gaul}

Compared to the very large amounts of imported goods discovered in Latenian Europe (Feugnet, in press), little is known about the

${ }^{2}$ Databases and inventories: PCR "Agglomerations antiques de Bourgogne, FancheComté et Champagne méridionale," BaseFer, ArkéoGIS, Benkert et al. (2010), Carrard (2009), Nortmann (2010), and Lenz-Bernhard and Bernhard (1991).

${ }^{3}$ See Filet (in press) for more details about modeling and incomplete inventories and outputs of confidence maps for this case study.

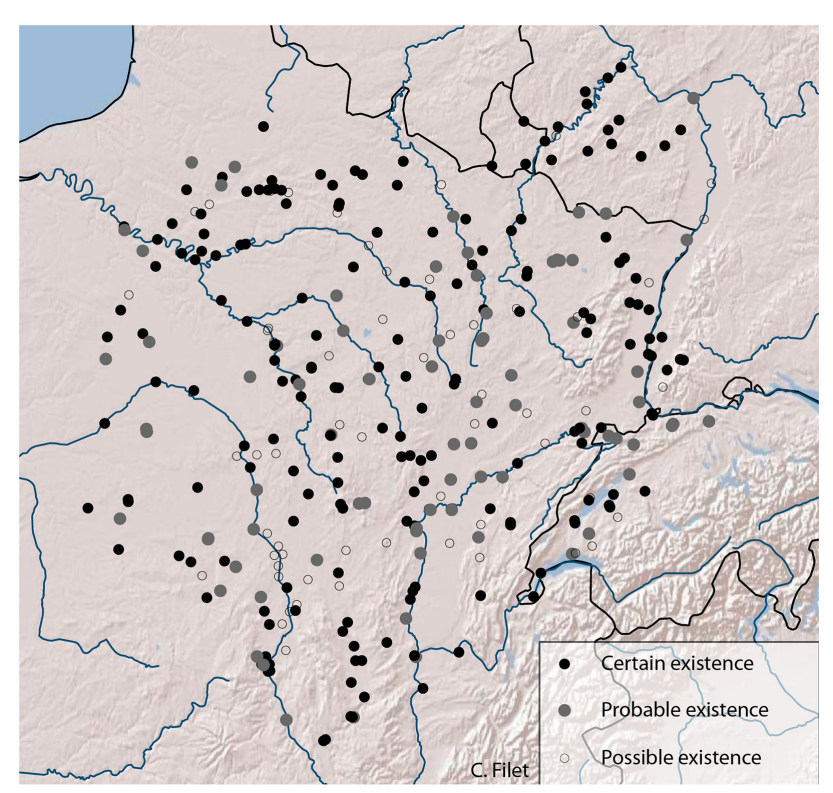

FIGURE 1 | Inventory of grouped habitats from 1 ha in the studied area Created by author (Basemap: Copyright (C) 2017 Esri. All rights reserved). practical ways of transit of those merchandises. The issue suffers from a lack of archeological evidence, as movements generally do not leave a trace, and as most of the means of transport were built from perishable raw materials (mostly wood). Nevertheless, it is assumed that two modes of transport may have been used to spread cumbersome goods across thousands of kilometers: roads and rivers (Salač, 2006, 2013).

Wagon loads are likely to have been the most used for land transportation. Already attested by both texts ${ }^{4}$ and rare archeological discoveries (as roads with ruts or iron wheel strapping), they were very convenient for the transport of heavy and cumbersome goods, alongside pack animals for more mountainous regions and lighter merchandise (Buchsenschutz, 2009; Salač, 2013). It is now assumed that the network of roads had already been widely developed.

The use of boats is also attested by texts, but none have been discovered yet. This method of transport would, however, have been essential for the mobility of goods, as particularly evidenced by the prosperity of settlements identified as harbors. However, the definition of the navigability of rivers remains highly subjective. It is strongly shaped by a range of different factors, from the differences in the shape and size of the boat used, the water regime and form of the river, the river portion considered and the season of travel. Furthermore, all those conditions could have evolved in time, even from La Tène to Roman Times. A synthesis of available data about fluvial navigation at the end of the Iron Age was developed from both ancient sources and recent studies in fluvial archeology, geomorphology, and history of technology. Considering the rivers located in the area of study presented above, we suggest a distinct minimum and maximum navigation terminus for each waterway, to overcome the limit of missing data about boat technology and the effect of seasonality. The publication of the result of this research is in preparation (Filet and Pasquini, in preparation).

\section{METHODOLOGY: SPATIAL INTERACTION MODEL AND ARCHEOLOGICAL DATA}

\section{Rihll and Wilson Model: Principles}

The Rihll and Wilson model belongs to the large family of spatial interactions models (Wilson, 1971), which are designed to give an estimation of the extent of interactions between entities from their spatial location (Sanders, 2001; Pumain and Saint-Julien, 2010). That model was first developed in the 1970s for economic geography frameworks. It originally aims to study the emergence of major retail centers in contemporary contexts and has now been extensively tested in a range of other disciplines (Rihll and Wilson, 1987).

The model works by estimating flows circulating between places and the benefits those places derive from those flows. The aim is to suggest a hierarchy of sites and links without any input knowledge about the intensity of interactions between the actors (cf. Appendix).

${ }^{4}$ Diodorus (V, 22), Strabon (IV, 1, 14), or even Cesar (I, 1, 6). 
Similar to most spatial interaction models, including gravity models, it uses one main external parameter: the sites' locations, from which can be derived the distance between them. Their weight (their importance: rank or size) can additionally be used [e.g., Davies et al. (2014)]. From those locations, the model inserts a uniform flow that is spread over the network. Each site picks up part of this flow according to its weight and its location. Then, it redistributes it again. The more flows a site gathers, the more its attractiveness (weight) increases and it appears as more important. The model then suggests a relative importance of agglomerations based on their location compared to the other places. This hierarchy is based on their estimated attractiveness, i.e., their ability to attract flows considering their locations.

The main interest for archeology in the model is that its formulation is almost independent of the database (Rihll and Wilson, 1987). Archeological data are generally heterogeneous. Their quantity and quality strongly rely on the intensity of research at a certain time. As some (rare) grouped habitats are fully excavated while we suppose the presence of others solely from surface survey, objective comparisons with a large set of diverse criteria still remain hopeless. However, this type of model uses a minimum of input data: the distance between sites from their relative location and their hierarchy. Fortunately, the location of sites is generally the basic data given by archeological operations, when defining their nature often remains a challenge. When hierarchical levels (based on their political rank, their relative size, or any other proxy) are taken into account, surfaces are distinguished into large clusters that mostly smooth their imprecisions. As for all the other information about a site that constitute the "empirical knowledge," they are used for validation and then do not need to be comparable. The strength of the model then lies in its applicability in a range of contexts where archeological data is poor, as long as they are sufficient to be measured against the outputs.

In the end, the Rihll and Wilson model uses the same basic parameters as other well-developed interaction models, such as the simple gravity model. ${ }^{5}$ The main difference consists in a dynamic network base that allows flows to spread from one center to another via several intermediate nodes. The simple gravity model may be appropriate to model unilateral relationships (as hierarchical relations). Rihll and Wilson's is, however, much more efficient in the modeling of dynamics (as trade flows).

\section{Objectives}

This model can be used in different ways. They differ according to the issues we raise and the importance of the information we have. Several scales can be interrogated: we can work on the whole system itself or look into particular regions or sites' features.

\section{Primary Outputs}

The model is first designed to suggest a hierarchy (in rank, size, or even population) of sites, i.e., a spatial distribution of sites' sizes for the studied region in a context of partial data (Rihll and Wilson, 1987; Wilson, 2012; Bevan and Wilson, 2013).

${ }^{5}$ Already widely used in archaeology (Nuninger et al., 2006; Guillon, 2013).

\section{Secondary Outputs}

(a) Accessibility then becomes a key term that can be estimated for each site based on its attractiveness and its distance to other sites (Wilson, 1971).

(b) The set of parameters that gives the best fit to real data can be looked for, allowing new considerations about geographical or political constraints in the studied area and their evolution through time (Davies et al., 2014; Palmisano and Altaweel, 2015).

(c) Issues about market area can be enriched by considering the flows themselves. From which sites each of them is receiving flows? As areas can be overlapping strict borders can be avoided (Wilson, 1971; Bevan and Wilson, 2013; Davies et al., 2014).

\section{Exploration}

The model can be used to verify if a site or a region is highly sensitive to condition changes: chosen parameters or missing sites (Rihll and Wilson, 1987). Rivers and Evans (2014) particularly worked on contingency and the effect of changing parameters on the outputs of the Rihll and Wilson model (see Evans and Rivers, this volume). ${ }^{6}$ It is also possible to interrogate regional dependencies; that is to say, to highlight the strong links that may make a region dependent on the dynamism of another one.

\section{Prediction}

The efficiency of the model is also recognized for its predictive potential. Its outputs can suggest unknown or poorly documented sites/regions as likely to be important (Rihll and Wilson, 1987; Bevan and Wilson, 2013).

\section{Recent Examples of Use in Archeology}

In addition to the original work on Archaic Greek city state formation by Rihll and Wilson, the model has been implemented for several case studies in archeology. Among the most recent publications, we cite Bevan and Wilson (2013), who investigated second millennium BC Crete and the development of palatial towns. Using 35 sites from the upper end of the settlement hierarchy from Middle-Late Bronze Age, they tried to identify sites that could have acted as central places. The aim was to distinguish a socioeconomic hierarchy from partial data. The analysis was coupled with a point process that enables to include potential missing sites. Settlements were connected through a nearest neighbors network which was weighted by the Eppstein method (1998). Real distances were calculated from a cost surface that would calculate the least cost path.

The model has also been applied to central Anatolia by Palmisano and Altaweel (2015). Two hundred seventy-four settlements from the Old Assyrian Colony period (1970-1700 $\mathrm{BC}$ ) were used to detect area/sites likely to become prominent and simulate their population growth. By varying parameters (interpreted in terms of ease of travel, attractiveness, and external contacts), the aim was to observe to which extent those factors

${ }^{6}$ Evans, T. S., and Rivers, R. J. "Was Thebes Necessary? Contingency in spatial modelling", Submitted to Frontiers in Digital Humanities as part of the Research Topic http://journal.frontiersin.org/researchtopic/4821 
played a role in the known significance of each site and in urban development in central Anatolia. Paths were also calculated from a Least Cost Path analysis and one factor was added to the original model to simulate external contacts.

Davies et al. (2014) from the University College of London applied the model to North East Syria. This time, two periods were investigated: Middle Bronze Age and Iron Age (respectively, representing 260 and 276 sites). They try to simulate a hierarchy of settlements that would be as close to archeological data as possible. The values of the needed parameters were then compared between the two periods and were used to bring new insights about economic and political constraints and their evolution.

Finally, we can mention the work of Rivers, Evans, and Knappett about the Aegean Sea concerning Bronze Age Aegean and Archaic Greek city states. Their publications mostly focus on comparing different spatial interactions models and discussing contingency in modeling (Rivers et al., 2013; Rivers and Evans, 2014).

Thus, in archeology, the model has mainly been applied to study urbanization processes. Except for the original Rihll and Wilson paper (1987), where they are calculated as the crow flies, distances rely on calculation from a Least Cost Path Analysis from the r.walk tool in GRASS GIS, which is optimized for walking journeys. However, see the paper by Evans, Rivers in this journal in which a variety of distance modeling is considered (see text footnote 6).

\section{Limitations}

Therefore, the Rihll and Wilson model is not a new model, even in archeology. Throughout applications of this model various complications have been experienced which we have to take into account in our own study.

\section{Defining Meaningful Parameters}

Indeed, most of the parameters used by the model cannot be precisely defined by a single value. How to strictly define navigability by a single end point on the river? Of course, its end will change from one season to another and according to the boat one uses. For all these boundless parameters, different possibilities from a minimal to a maximal point have to be tested, in order to perceive which structures remain robust, i.e., are maintained despite the variation of parameters. Only those robust structures can then be taken into account.

\section{Neighborhood \\ As experienced by Davies et al. (2014) and Rivers and Evans (2014), in some cases, the behavior of Rihll and Wilson model highlights a general area where an important site is to be expected rather than the exact location of a dominant site. In a cluster of close sites, if the algorithm emphasizes one in particular, it sometimes indicates that according to the model an important site should emerge in its neighborhood. Again see Evans and Rivers (2017), this journal, for a more detailed analysis (see text footnote 6).}

\section{Preventing Edge Effects}

As always when considering most networks systems, the delimitation of the study remains problematic. How to consider the interactions with regions situated outside of the studied area? This constraint has been treated differently in various publications. In Bevan and Wilson's work (Bevan and Wilson, 2013), which uses the natural see border of Crete, the interactions with neighboring regions overseas is directly added to coastal settlements by including an extra inflow. For Davies et al. (2014), this influence is directly added in the model's parameters.

\section{Models: Expectations vs. Reality}

The Rihll and Wilson function is a model, which means that it builds a schematic representation of reality developed for a demonstration (Haggett, 1965). It consists of an idealized picture of the reality to highlight some of its properties (Haggett, 1973). Indeed, one model, as sophisticated as it can be, will never solve a complex problem. A model does not tell what is happening, it cannot describe the reality. But it is able to test, try, confront, and explore the complexity of a phenomenon and help to explain some of its elements. Then, every modeling is a tool, which is never to be interpreted directly. It becomes relevant after several runs between outputs and real data. However, if some features are maintained in the model despite the variation of parameters, then they are likely to have been important.

\section{USING RIHLL AND WILSON MODEL FOR THIS CASE STUDY}

The case study presented here relies on the same model and close issues as those previous works: using the Rihll and Wilson model to bring new elements to the understanding of an ancient urbanization process. However, it will differ in two ways: the definition of the distances and the importance given to phenomena that are unpredicted by the model.

\section{Defining a Commercial Space}

As this study focuses on trade flows, space will be structured by different distances from those calculated for individual walkers. In our case, distances are defined by the difficulty of reaching a place transporting cumbersome and heavy goods on longdistance trade journeys. Ultimately, they will be calculated from a multimodal Least Cost Path Analysis, using wheeled vehicles for land travels and boats for river journeys (upstream and downstream). These optimized paths will then be weighted by the ratio corresponding to the cost of each way of transportation. Those new distances will then define a commercial space which will be different from the geographical space. Two places are considered as close if the cost for going from one to the other (dependent on the means of transportation used to travel) is low. In other words, two sites linked by a navigable portion of river will be treated as closer than two other sites distant by the same number of kilometers by land.

The definition of cost ratios for each way of transportation strongly depends on technology and infrastructure. As well as navigability, the aim is not to provide strict values for cost for each means of transportation. That would be meaningless considering that they obviously evolve in time, from one period to another and from winter to summer. They also should have been different according to the transported goods. However, we should be able 
to perceive a general balance between the different ways, and then use different ratios accordingly. The published studies about cost of transportation in different areas and periods of time agree that the heavier and more cumbersome the transported goods are, the more the ratio is in favor of river travel (Dyos and Aldcroft, 1969; Duncan-Jones, 1974; Kunow, 1980; Carreras Monfort, 2000). Although this means of transport is always less costly than land travel, up river and down river are still to be distinguished, the second one being the fastest and easiest. To be more specific, we considered the several studies about those costs in Roman times, which are the closest to our area and period of study [e.g., Kunow (1980) and Carreras Monfort (2000)]. Most of them are based on the Edict of Maximum Price, a roman edict issued in $301 \mathrm{AD}$. However, we assume that gaps in costs between land and river travel increased during the Roman Empire, thanks to the development of new boat technologies and river shorelines. All those studies and assumptions helped to establish different cost ratios, considered as proxies for the supply difficulties of each way of transportation, which are to be implemented in the model. Once again, only the results that are independent of the variation of the parameters will be considered.

\section{On the Use of Models}

From those distances based on costs, flows are determined with the Rihll and Wilson model, which enables us to model the diffusion of flows in a network and how it ends up favoring certain settlements. To our knowledge, it is the model that best represents the constraints to take into account when working on the diffusion of trade flows. It allows us to consider several economic factors of the attractiveness of a town for merchants: the concentration of population, the fact that already significant commercial activities attract flows, and the ease of access. However, we are perfectly aware that those parameters do not explain everything of the movement of merchants and the commercial status of a town.

As only one factor (trade flows) will be considered from all those can explain the emergence, the prosperity, and the importance of an agglomeration, it is certain that the picture given by the model will not be the reflection of the real hierarchy of settlements at La Tène times. The relevance of modeling arises from the confrontation with complex real data, based on which trends can be suggested. For example, we want to emphasize that the prominence of the regions, as highlighted by the model, corresponds to a known economic status in empirical data, suggesting that its location inside the trade network actually played a role. Similarly, cases where this factor does not seem to be relevant to explain their prosperity should be perceived through the divergence between the outputs of the model and real data. Indeed, convergence and gaps are as valuable in the use of models. For our case, if we can assume that this gap is not linked with missing data, the disagreement could be linked to other factors that are not taken into account in the model (such as political status or previous prominence). On the contrary, we can also imagine areas that will be overestimated by the model comparing to their low importance at that time, which may emphasize that these regions could have had structural potentials for communication, but with non-interesting partners or that they could not/did not want to take advantage of it.

\section{Exemplary Output}

We conclude this analysis with a demonstrative example, based on 67 sites dated from La Tène D1 (Figure 2). All the settlements are agglomerations from 7 to 240 ha (smaller were excluded), but size classes (weight) are not defined. Only the distance between sites is considered. The visualization presented here is obtained

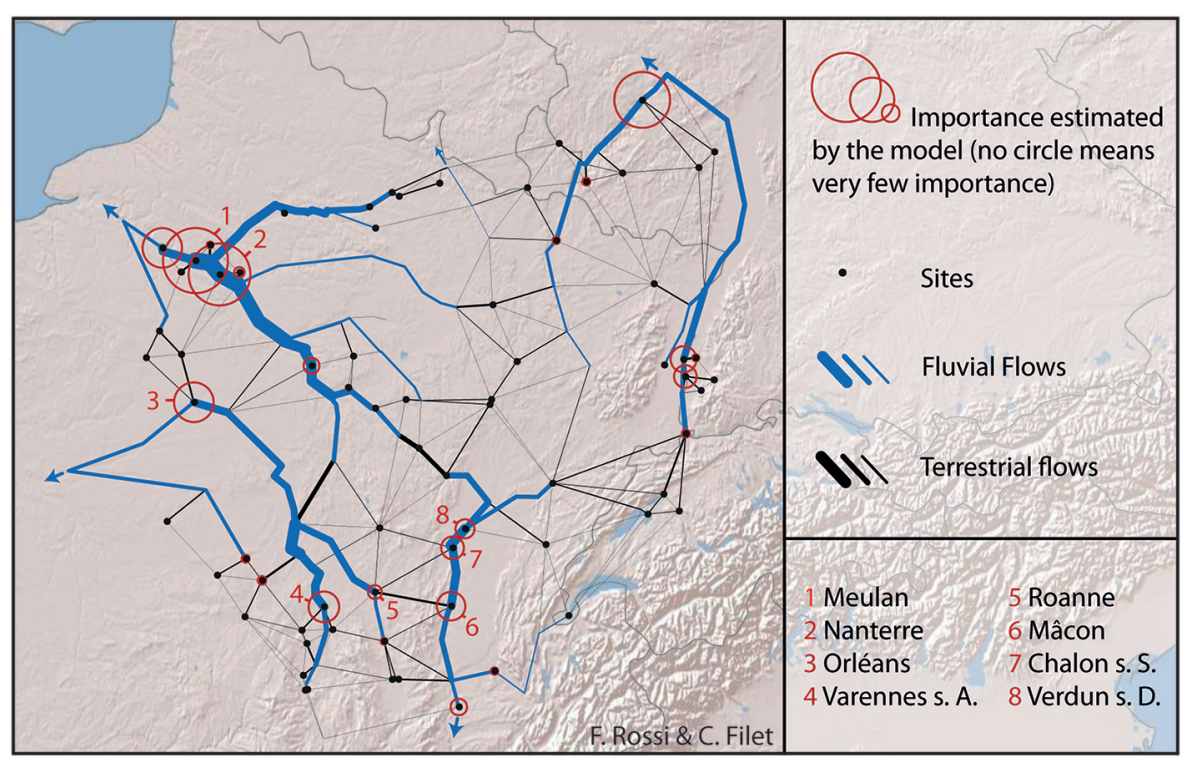

FIGURE 2 | Exemplary output for settlements of more than 7 ha and dated from LT D1. Created by author (Basemap: Copyright @ 2017 Esri. All rights reserved). 
from an abstract space where the transport system distinguishes land and river travel (upstream and downstream), but with terrestrial paths calculated as the crow flies.

As the cost ratio particularly benefits to river paths, it is not surprising that the major flows follow the main rivers. From the 67 input sites, a dozen settlements are particularly underlined by the model. In the Parisian Basin, Meulan, Nanterre, and several other open agglomerations in the surroundings (Bobigny and Epiais-Rhu) seem significantly favored by downstream flows from several confluences (Seine, Oise, Marne). Orléans stands out as remarkable in the Loire Basin. Orléans stands out as remarkable in the Loire Basin. This statement is consistent with both archeological and historical knowledge, which place it as a major economic center of Carnute people ${ }^{7}$. The picture well emphasizes that this prominent status can notably be explained by the role of this city as an intermediary node to travel from the Loire basin to northern areas and the Eure and Seine Rivers. Varennessur-Allier and Roanne seem to benefit from the same position as crossroads between terrestrial and fluvial paths on the Allier River on the one hand and upstream Loire River on the other. Finally, Mâcon, Chalon-sur-Saône, and Verdun-sur-le-Doubs are highlighted as the three main nodes of the Saône and Rhône Basin. If Mâcon is still not well known by archeologists, the two others are already pointed out as essential economic hubs on the Saône River by the literature (Billoin et al., 2009; Barral and Lallemand, 2014). Tens of thousands of Roman amphorae were discovered in the River near Chalon-sur-Saône (see Feugnet, 2018).

Even with very few parameters (mostly the distance in cost between sites), this first output is quite consistent with the empirical knowledge. All the underlined settlements are known to have been important commercial centers. The sizes of each point are, however, not to be interpreted directly, naively saying that Meulan or Nanterre were economically stronger than Varennes-surAllier. It only emphasizes that all those sites were not disfavored by their location, and that it could have had an impact in their development and prosperity.

Those model runs have to be replicated in the future, using another selection of the dataset (as including the smallest sites or another time slice) and by varying parameters (adding the size, changing the navigability end-points, etc.). The terrestrial paths also need to be obtained from a Least Cost Paths analysis, to avoid unlikely direct connections through mountainous areas (such as the links crossing the Alps in the picture). This is, however, an encouraging first step. It clearly demonstrates that this kind of modeling has much to offer in the study of ancient urbanization systems, such as the emergence of the first Latenian cities.

\section{Expected Results}

Several scales and issues will be investigated from the outputs of the model. The first step is to look at the overall structure and measure against real data. To what extent do the estimated "trade" flows directed by the cost of transportation efficiently reflect the known hierarchy of agglomerations in this area? Considering the evolution through the different time slices, is the model more or less effective for a certain period? If the model, directed by estimated

${ }^{7}$ Ceasar, Commentarii de Bello Gallico, VII, 3; Strabo, Geographica, IV, $2,3$. commercial flows, is not sufficient to reflect the global structure of settlement hierarchy at one particular period, but works well for the others, then two possibilities can be suggested: that the weight of missing sites is too important, or that it highlights a proper archeological feature. If so, this could indicate strongly that for this period in particular, other factors than trade flows may have had a stronger impact on the settlement hierarchy.

The second set of issues concerns the classification of the settlements. Which types of sites seem to be favored based on their position in the network? This question is directly linked to the traditional classification between open agglomerations, usually perceived as craft and trade centers, and the so-called oppida, the fortified towns that may have had stronger political and religious functions (Fichtl, 2005; Augstein, 2006; Filet, 2014). Several contentions about the difference in landscape location have been put forth, suggesting that valleys and proximity to a river would have been looked for in the case of open agglomerations, to get close to the main communication roads, whereas most of the fortified settlements preferred less accessible locations on hilltops (Fichtl, 2013). This assertion derives from the observation of individual positions mostly at local scales. However, the use of the model should help see how far that statement could be consistent considering the estimated general spread of trade flows. The output hierarchy should then mostly emphasize the open settlements.

For the latest time slices, the fitting of the outputs with the political hierarchy should also be investigated. The position of the coupled sites Bibracte (the capital of the Aedui) and Chalon-surSaône (its rich access to the river situated $60 \mathrm{~km}$ away) suggests that for some regions the political center is not always among the towns that maintains the structure of the commercial network in the area. The model can help highlight other similar cases and bring forth new elements to understand the role of secondary towns in the trade network.

The same can hold true for the smallest sites. If the model is run solely from the biggest settlements, are they sufficient to suggest a picture close to reality? Or are small intermediaries necessary to ensure the spread of modeled flows? Besides, a further dataset including only the smallest settlements should be tested, to observe how far the output picture obeys other rules.

The third range of issues concerns the regional dependencies. In an interaction network, to which trade relationships belong, a place can become important not only because it is involved in a lot of connections but also because it works as an intermediary through which more distant connections can be maintained. ${ }^{8}$ In addition to measuring betweenness' diversity, this issue can easily be approached through the model, by removing regional entities from the input data and seeing how far the significance of the neighboring area is impacted.

The other issue of market area and boundaries was already addressed by Bevan and Wilson (2013) in their work on Palatial Crete. It aims to determine from the model the main partners of each site, i.e., its main creditors and debtors, and to determine a hierarchy of the links based on their degree of dependence. Projected on a map, those local theoretical hierarchies allow us

${ }^{8}$ This distinction refers to two different measures of centrality in Graph Theory and Network Analysis: degree and betweenness' centrality (Collar et al., 2015). 
to reflect on the extent of possible market areas that are solely determined by the location of settlements and their accessibility. Then, they need to be compared with our empirical knowledge about differences in material cultures, as well as the political division of the Civitates.

If all those questions focus on the settlements themselves, the modeling can also be useful to work on the links and estimated paths. As several connections with different degrees of intensity can use the same paths, the relative popularity of a link can be determined (Bevan and Wilson, 2013). For example, if the connection between Malain and Alesia (Côte d'or, France) is the shortest path to link the settlements situated along the Saône valley and those of the Seine valley, then this connection will be emphasized as particularly important. Those elements may become truly valuable for reflecting on the paths of transport and the general area where main roads are to be expected.

This study can also be used to bring some new elements about individual sites trajectories. Which sites are always accurately estimated by this trade flows model? Which never are? Does the model fit with the empirical hypothesis about why a site appeared at this location (presence of local raw material, pre-existing sanctuary or gathering place, etc.)? Then, the model can be applied in a more exploratory way: what happens if we remove an important intermediary?

Finally, the point is to observe how all those elements seem to evolve in time through the five time slices. It has to be noted that we possess a relatively good precision of dating in the area, much more than on the other zones where this model has been applied in archeology. It allows us to work with relatively short time slices spanning few decades. By applying the model and working on its outputs for all of them, we aim to follow the gradual setting up of the urbanization process in this area.

\section{REFERENCES}

Augstein, M. (2006). Offene Siedlungen der Mittel-und Spätlatènezeit in Mittelund Westeuropa. Archäologische Informationen 29:205-210. doi:10.11588/ ai.2006.1\&2.11115

Barral, P., and Lallemand, D. (2014). Les agglomérations ouvertes du IIe siècle av. J.-C. à spécialisation artisanale et commerciale: deux exemples du Centre-Est de la France, Varennes-sur-Allier (Allier) et Verdun-sur-le-Doubs (Sâone-et-Loire). In Produktion - Distribution - Ökonomie, Siedlungs- und Wirtschaftsmuster der Latènezeit, Akten des internationalen Kolloquiums in Otzenhausen, 28.-30. Oktober 2011, Edited by S. Hornung, 205-230. Bonn: Verlag Dr. Rudolf Habelt GmbH.

Bar-Yam, Y. (2003). Dynamics of Complex Systems. Boulder, CO: Westview Press.

Benkert, A., Curdy, P., and David-Elbiali, M. (2010). "Sites de hauteur et contrôle du territoire aux âges des métaux dans la vallée du Rhône (Suisse/Cantons du Valais et de Vaud)," in Les Alpes dans l'Antiquité XII, 2009 Octobre 2-4, Vol. XXI, Yenne, Aoste, 171-191.

Bevan, A., and Wilson, A. (2013). Models of settlement hierarchy based on partial evidence. Journal of Archaeological Science 40: 2415-2427. doi:10.1016/j. jas.2012.12.025

Billoin, D., Bonnamour, L., Mouton, S., and Videau, G. (2009). Lagglomeration de Chalon-sur-Saône de La Tène finale au début de la période gallo-romaine: un port comptoir aux origines de Cabilonnum. In Lâge du Fer dans la boucle de la Loire. Les Gaulois sont dans la ville, Vol. 2008, Edited by O. Buchsenschutz, M.-B. Chardenoux, S. Krausz, and I. Ralston (dir.), 263-278. Bourges: Actes du colloque de l'AFEAF.

Brun, P. (2015). Lévolution en dents de scie des formes d'expression du pouvoir durant l'âge du Fer en Europe tempérée. In: Les structures sociales protohistoriques

\section{CONCLUSION}

The Latenian urbanization process is now considered as an internal evolution at a time of intense economic, technical, demographical, social, and spiritual changes. The urban response to those new challenges of the society can be seen both as a cause and consequence. This response was made easier in that interactions and long-distance contacts literally exploded.

We assume that centrality in the exchanges network is one of the key factors to study the complexity of the urbanization, and that it could be partly perceptible from the settlements location. This article aimed at presenting how interactions modeling can be used to investigate this centrality of towns. We hope that this ongoing project will provide new perspectives about the impact of trade interactions on the growth and the prosperity of developing cities.

Once the broad and obvious commercial factor is ruled out, we can start investigating the other reasons why those cities became prominent in their area: raw materials, religious significance, local strategies, etc.

\section{AUTHOR CONTRIBUTIONS}

The Project and writing were performed by CF.

\section{ACKNOWLEDGMENTS}

The author thanks Fabrice Rossi, Julien Randon-Furling (SAMM-Paris 1), and Ray Rivers (Imperial College of London) for all their precious guidance and advice. She is also grateful to Aurélia Feugnet, Patrice Brun (ArScAn and AOROC-Paris 1), and Doina Jaravin for their support and their time for proofreading.

en Gaule et Ibérie, VIIe réunion internationale d’archéologie de Calafell, March 2013, Calafell.

Buchsenschutz, O. (2009). Chars, charettes et transport dans l'agriculture celtique. In Habitats et paysages ruraux en Gaule et regards sur d'autres régions du monde celtique; actes du XXXIe colloque international de l'AFEAF, 17-20 mai 2007, Chauvigny, 85-92. Chauvigny: Association des publications chauvinoises.

Carrard, F. (2009). "Organisation territoriale et espaces ruraux à La Tène finale en Suisse occidentale: un état des questions," in Habitats et paysages ruraux en Gaule et regards sur d'autres régions du monde celtique; actes du XXXIe colloque international de l'AFEAF, 2007 Mai 17-20, Vol. 321, Chauvigny, 361.

Carreras Monfort, C. (2000). Economía de la Britannia romana: la importación de alimentos. Barcelona: Publicación Universitat de Barcelona.

Cauuet, B., and Tamas, C. (2008). "Loppidum de Bibracte. Les exploitations minières," in Bilan de 10 années de recherches (1996-2005), eds L. Dhennequin, J.-P. Guillaumet, and M. Szabo (Budapest: Academiae Scientiarum Hungaricae), $11-12$.

Collar, A., Coward, F., Brughmans, T., and Mills, B. (2015). Networks in archaeology: phenomena, abstraction, representation. J. Archaeol. Method Theory 22, $1-32$.

Collis, J. (1984). Oppida: earliest towns north of the Alps. Sheffield, England: Dept. of Prehistory and Archaeology, University of Sheffield.

Collis, J., Krausz, S., and Guichard, V. (2000). Les villages ouverts en Gaule centrale aux IIè et Ier s. av. J.-C. In Les processus d'urbanisation à l'âge du Fer = Eisenzeitliche Urbanisationsprozesse: actes du colloque tenu à Bibracte, Glux en Glenne, 8-11 juin 1998, Vol. 4, 73-82. Glux-en-Glenne: Bibracte/Centre archéologique européen.

Davies, T., Fry, H., Wilson, A., Palmisano, A., Altaweel, M., and Radner, K. (2014). Application of an entropy-maximizing and dynamics model for understanding 
settlement structure: the Khabur Triangle in the Middle Bronze and Iron Ages. Journal of Archaeological Science 43: 141-154. doi:10.1016/j.jas.2013.12.014

Duncan-Jones, R. (1974). The Economy of the Roman Empire: Quantitative Studies. Cambridge: University Press.

Dyos, H. J., and Aldcroft, D. H. (1969). British Transport: An Economic Survey from the Seventeenth Century to the Twentieth, London: Leicester University Press.

Evans, T., Rivers, R., and Knappett, C. (2012). Interactions in space for archaeological models. Advs. Complex Syst. 15:1150009. doi:10.1142/S021952591100327X

Feliu, C. (2008). Leuques et Médiomatriques à La Tène moyenne et finale, Organisation sociale et territoriale de l'habitat dans deux cités du nord-est de la Gaule du IIIe au Ier siècle avant notre ère. Strasbourg.

Fernández-Götz, M. (2014a). Identity and Power: The Transformation of Iron Age Societies in Northeast Gaul. Amsterdam: Amsterdam University Press.

Fernández-Götz, M. (2014b). Reassessing the Oppida: the role of power and religion. Oxford Journal of Archaeology 33: 379-394. doi:10.1111/ojoa.12043

Fernández-Götz, M., Wendling, H., and Winger, K. (2014). Paths to Complexity: Centralisation and Urbanisation in Iron Age Europe. Oxford: Oxbow Books.

Feugnet, A. (2018). Le choix, très sélectif, des importations grecques et romaines dans les sociétés celtiques (250-25 av. n. è.). Paris: Paris 1 Panthéon-Sorbonne.

Fichtl, S. (2005). La ville celtique: les oppida de 150 av. J.-C à 15 ap. J.-C (Ed. corr. et augm). Paris: Errance.

Fichtl, S. (2012). Les peuples gaulois: IIIe-Ier siècles av. J.-C. Paris: Errance.

Fichtl, S. (2013). Les agglomérations gauloises de la fin de lâge du Fer en Europe celtique (IIIe-Ier siècle av. J.-C.). In L'habitat en Europe celtique et en Méditerranée préclassique - Domaines urbains, Edited by D. Garcia, 19-43. Paris: Errance.

Fichtl, S., Metzler, J., and Sievers, S. (2000). Le rôle des sanctuaires dans le processus d'urbanisation. In Les processus d'urbanisation à lâge du Fer = Eisenzeitliche Urbanisationsprozesse: actes du colloque tenu à Bibracte, Glux en Glenne, 8-11 juin 1998, Vol. 4, 179-186. Glux-en-Glenne: Bibracte/Centre archéologique européen.

Filet, C. (2014). New approaches to the Celtic urbanisation process. Dig It 2: 19-27.

Garmy, P. (2012). Villes, réseaux et systèmes de villes: contribution de l'archéologie. Arles: Errance; Actes sud.

Gruel, K. (1989). La monnaie chez les gaulois (Errance). Paris: Errance.

Guillon, E. (2013). Les arrière-pays des cités phéniciennes à lépoque héllénistique, IVe siècle-IIe siècle ap. J.-C: approches historiques et spatiales d'une aire géoculturelle. Toulouse: Université de Toulouse-Le Mirail.

Haggett, P. (1965). Locational Analysis in Human Geography. Londres: Arnold.

Haggett, P. (1973). L’analyse spatiale en géographie humaine. Paris: A. Colin.

Kasprzyk, M., and Nouvel, P. (2010). Du Val de Saône au nord-ouest de la Gaule: le passage du Morvan de la fin de la protohistoire au Haut Moyen Age. In Routes du monde et passages obligés: de la Protohistoire au haut Moyen Âge: actes $d u$ colloque international d'Ouessant, 27-28 septembre 2007, Edited by J.-P. Le Bihan, 223-251. Quimper: Centre de recherche archéologique du Finistère.

Krausz, S. (2014). Territoires et sociétés protohistoriques du Néolithique à lâge du Fer, Thèse d'Habilitation à Diriger des Recherches (Thèse d'habilitation). Paris: Consulté à l'adresse $\mathrm{o}$.

Kruta, V., and Goudineau, C. (1980). La Gaule intérieure, Y a-t-il une ville protohistorique? In Histoire de la France urbaine, T. 1 La ville antique: des origines au IXe siécle, Edited by G. Duby, 195-229. Paris: Éd. du Seuil.

Kunow, J. (1980). "Negotiator et Vectura. Händler und Transport im freien Germanien," in Kleine Schriften aus dem Vorgeschichtlichen Seminar, Vol. 6. Marburg, 1-37.

Lallemand, D. (2008). Le département de l'Allier au carrefour des Arvernes, des Bituriges et des Eduens, IIIè-Ier siècles avant J.-C. Paris: Université Paris Pantéon-Sorbonne.

Lenz-Bernhard, G., and Bernhard, H. (1991). Das Oberrheingebiet zwischen Caesars Gallischem Krieg und der flavischen Okkupation (58 v.-73 n.Chr.) Eine siedlungsgeschichtliche Studie. Speyer: Verlag des Historischen Vereins der Pfalz.

Malrain, F. (2000). Fonctionnement et hiérarchies des fermes dans la société gauloise du IIIème siècle à la période romaine: l’apport des sites de la moyenne vallée de l'Oise. Paris: Paris 1 Panthéon-Sorbonne.

Malrain, F., Matterne, V., and Méniel, P. (2002). Les Paysans Gaulois. Paris: Errance.

Marion, S. (2013). L'économie du IIIe siècle a.C., 20 ans après. In Lâge du fer en Europe. Mélanges offerts à Olivier Buchsenschutz, 361-369. Bordeaux.

Metzler, J. (1995). Das treverische Oppidum auf dem Titelberg (G.-H. Luxemburg): zur Kontinuität zwischen der spätkeltischen und der frührömischen Zeit in NordGallien. Luxembourg: Musée national d'histoire et d'art.
Moore, T., and Ponroy, C. (2014). What's in a Wall? Considerations on the Role of Open settlements in Late La Tène Gaul. In Paths to Complexity: Centralisation and Urbanisation in Iron Age Europe, Edited by M. Fernández-Götz, H. Wendling, and K. Winger, 140-155. Oxford: Oxbow Books.

Nortmann, H. (2010). Befestigungen der Eisenzeit im Hunsrück-Nahe-Raum, Forschungsstand, Fragen und Hypothesen. Trierer Zeitschrift 71-72, 2008/2009.

Nuninger, L., Sanders, L., Favory, F., Garmy, P., Raynaud, C., Rozenblat, C., et al. (2006). La modélisation des réseaux d'habitat en archéologie: trois expériences. M@ppemonde 83: 1-28.

Olmer, F., Verrier, G., Girard, B., and Bohbot, H. (2013). Voies, acteurs et modalités du grand commerce en Europe occidentale. In Mobilité des hommes, diffusion des idées, circulation des biens dans l'espace européen à l’àge du Fer - 35e colloque international de l'AFEAF, Vol. 30, 667-693. Bordeaux.

Oštir, K., Kokalj, Ž, Saligny, L., Tolle, F., and Nuninger, L. (2008). Confidence maps: a tool to evaluate archaeological data's relevance in spatial analysis. In Layers of Perception. Proceedings of the 35th International Conference on Computer Applications and Quantitative Methods in Archaeology (CAA), Berlin, 2.-6. April, 2007, Edited by A. Posluschny, K. Lambers, and I. Herzog, 272-277. Bonn.

Palmisano, A., and Altaweel, M. (2015). Simulating past human landscapes: models of settlement hierarchy in Central Anatolia during the Old Assyrian Colony period. Subartu 35: 131-146.

Pierrevelcin, G. (2010). Les relations entre la Bohême et la Gaule du IVème au Ier siècle av. J.-C. Prague, Strasbourg: Consulté à l'adresse oo.

Pumain, D., and Saint-Julien, T. (2010). Lanalyse spatiale: Les interactions. Paris: A. Colin.

Rihll, T., and Wilson, A. (1987). Model based approaches to the analysis of regional settlement structures: the case of ancient Greece. In History and Computing, Vol. 2, Edited by P. Denley and D. Hopkin, 10-20. Manchester: Manchester Univ. Pr.

Rivers, R., and Evans, T. (2014). New approaches to Archaic Greek settlement structure. Les Nouvelles de l'Archéologie, Analyse des Réseaux sociaux en archéologie 135: 21-27.

Rivers, R., Knappett, C., and Evans, T. (2013). What makes a site important? Centrality, gateways and gravity. In Network Analysis in Archaeology: New Approaches to Regional Interaction, 125-150. Oxford: Oxford University Press.

Salač, V. (2006). O obchodu v pravěku a době laténské především - On trade in prehistory, and especially in the La Tène Period. Archeologické Rozhledy, 88, 33-58.

Salač, V. (2013). De la vitesse des transports à lâge du Fer. In Mobilité des hommes, diffusion des idées, circulation des biens dans lespace européen à lâge du Fer-35e colloque international de l'AFEAF, Vol. 30, 489-512. Bordeaux.

Salač, V. (2014). Oppida and urbanisation processes in Central Europe. In Paths to Complexity: Centralisation and Urbanisation in Iron Age Europe, Edited by M. Fernández-Götz, H. Wendling, and K. Winger, 64-75. Oxford: Oxbow Books.

Sanders, L. (2001). Les modèles en analyse spatiale. Cachan: Hermes-Lavoisier.

Séguier, M. (1996). Varennes-sur-Seine "Le Marais du Pont". Rapport final d’opération de fouille préventive (DFS). Paris: SRA.

Vaginay, M. (2000). Lieux de pouvoir et symbolique des lieux, Ville et espace social en Gaule au 2nd âge du Fer. In La question de la Proto-Urbanisation à l'âge du Fer, Acte du 34ème colloque de l'AFEAF, Edited by S. Sievers and M. Schönfelder, 365-386. Aschaffenburg: Römisch-Germanische Kommission, Frankfurt.

Wilson, A. (1971). A family of spatial interaction models, and associated developments. Environment and Planning 3: 1-32. doi:10.1068/a030001

Wilson, A. (2012). Geographical modelling for archaeology and history: two case studies. Advances in Complex Systems 15: 1-14. doi:10.1142/S0219525911003384

Conflict of Interest Statement: The author declares that the research was conducted in the absence of any commercial or financial relationships that could be construed as a potential conflict of interest.

Copyright (๑) 2017 Filet. This is an open-access article distributed under the terms of the Creative Commons Attribution License (CC BY). The use, distribution or reproduction in other forums is permitted, provided the original author(s) or licensor are credited and that the original publication in this journal is cited, in accordance with accepted academic practice. No use, distribution or reproduction is permitted which does not comply with these terms. 


\section{APPENDIX}

The functioning of the Rihll and Wilson model was already detailed and explained in numerous publications. For further developments, see Bevan and Wilson (2013), Davies et al. (2014), Evans et al. (2012), and Palmisano and Altaweel (2015).

Given data:

$W_{i}$, original attractivity;

$C_{i j}$, distance between $i$ and $j$.

Model variations:

$\alpha$, importance of original scale or weight on attractivity;

$\beta$, ease to travel or weight on distances.
Parameters to estimate:

$T_{i j}$, total of flows between $i$ and $j$.

The spatial interaction model itself can be represented as

$$
T_{i j}=\frac{O_{i} W_{j}^{\alpha} e^{-\beta_{C_{i j}}}}{\sum_{k} W_{k}^{\alpha} e^{-\beta_{C_{i k}}}}
$$

where $O_{i}$ is the measure of the flows originated at $I$, and $k$ the other settlements receiving flows from $i$. The influence of flows arriving at $j$ on its attractivity is expressed by

$D_{i j}=\sigma_{i} T_{i j}$, sum of the inflows attracted by $j$;

$\Delta W_{j}=\varepsilon\left(D_{j}-K W_{j}\right)$, variation of the attractivity of $j\left(W_{j}\right)$. 